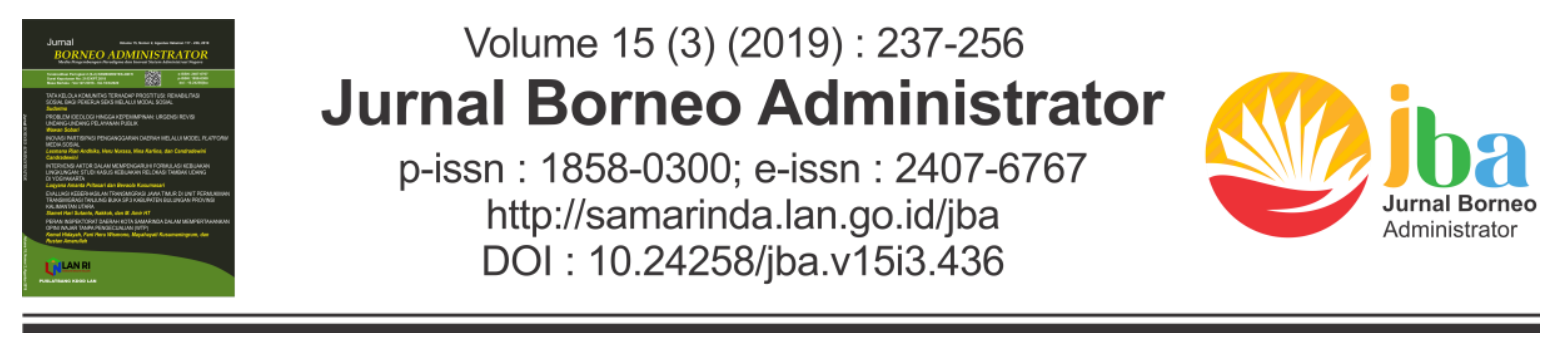

\title{
INSTITUTIONAL PLURALISM SISTEM PERADILAN INDONESIA DAN KEKUATAN NEGARA DI ERA GLOBALISASI
}

\section{INSTITUTIONAL PLURALISM OF INDONESIA'S JUSTICE SYSTEM AND STATE'S POWER IN GLOBALIZATION ERA}

\author{
Bambang Irawan \\ Kepala Laboratorium Kebijakan Publik Universitas Mulawarman \\ Fakultas IImu Sosial dan IImu Politik Universitas Mulawarman \\ Jl. Muara Muntai, Kampus Gunung Kelua, FISIP Unmul, Samarinda \\ Email: bambangirawan@unmul.ac.id
}

Naskah diterima: 16 Januari 2019; revisi terakhir: 19 September 2019; disetujui 28 Oktober 2019

How to Cite: Irawan, Bambang. (2019). Institutional Pluralism Sistem Peradilan Indonesia dan Kekuatan Negara di Era Globalisasi. Jurnal Borneo Administrator, 15 (3), 237-256. https://doi.org/10.24258/jba.v15i3.436

\begin{abstract}
This article comes from the argument saying that the main indicator for measuring a state's power is based on its endurance survival. Borrowing the concepts developed by International Relations and Public Administration, this article aims to describe the concept of a state's power and its relations to administrative setting. Traditionally, state's power is measured by its ability to affect the environment (external), however, the contemporary trend suggests that state's power is leaning more and more towards the state ability to serve the demand of its people(internal)One of the global issues concerns to the ability of a state to fulfill justice and security internally. In Indonesian context, its judicial system and institutions revolve around three main institutions, the Supreme Court, the Constitutional Court, and the Judicial Commission. The institutional reform of Indonesia's justice system is intended to maintain accountability and reflect an institutional pluralism model. However, the model does not necesarily create a high level of public confidence towards the Indonesian judicial system, and later, it will affect Indonesia's survivability.
\end{abstract}

Keywords: Judicial System and Institutions of Indonesia, Institutional Pluralism, State's Power, Survivability

\begin{abstract}
Abstrak
Artikel ini bertitik tolak dari argumen yang mengatakan bahwa indikator utama dari kekuatan suatu negara adalah sejauh mana ia bisa menjaga eksistensinya (survival). Meminjam konsep-konsep yang dikembangkan dalam studi Hubungan Internasional dan Administrasi Publik, artikel ini bertujuan untuk mendeskripsikan konsep kekuatan Negara serta hubungannya dengan tatanan administratif dari suatu Negara tersebut. Jika secara tradisional kekuatan Negara sering kali diukur melalui kemampuan untuk
\end{abstract}


memengaruhi lingkungan (eksternal), maka kecenderungan yang terjadi pada era kontemporer menunjukkan bahwa konsep kekuatan negara perlahan semakin bergeser pada penekanan terkait kemampuan Negara tersebut untuk melayani tuntutan masyarakatnya (internal). Salah satu isu global yang yang menjadi perhatian adalah kemampuan Negara untuk memenuhi rasa keadilan dan keamanan (order, justice dan security) di tengah masyarakat. Dalam konteks Indonesia, sistem dan lembaga peradilan berfokus pada tiga institusi yakni Mahkamah Agung, Mahkamah Konstitusi dan Komisi Yudisial. Reformasi kelembagaan sistem peradilan Indonesia dimaksudkan untuk menjaga akuntabilitas serta merefleksikan model institutional pluralism. Meski demikian, model tersebut tidak serta merta berdampak pada tingginya kepercayaan publik terhadap sistem peradilan Indonesia, dan pada gilirannya akan berpengaruh terhadap survivability Indonesia.

Kata Kunci: Sistem dan Lembaga Peradilan Indonesia, Institutional Pluralism, Kekuatan Negara, Survivabilitas

\section{A. PENDAHULUAN}

Kekuatan (power) sebagai salah satu konsep utama dalam Ilmu Politik adalah konsep yang banyak memantik perdebatan diantara para penstudi. Namun dari sekian banyak definisi yang tersedia, agaknya kekuatan lebih mudah untuk dimengerti dengan definisinya sebagai "suatu kemampuan untuk membuat pihak lain melakukan sesuatu sesuai dengan apa yang kita inginkan, meskipun pihak lain tersebut tidak menginginkannya". Definisi ini adalah definisi yang banyak digunakan dalam studi Ilmu Hubungan Internasional (HI) terkait dengan keperluan untuk menganalisis relasi antar aktor HI terutama Negara.

Meski demikian seiring dengan perubahan yang terjadi pada skala global maka definisi dari konsep itu turut bertransformasi. Globalisasi sebagai suatu fenomena yang menembus batas-batas Negara membawa serta isu-isu baru dalam kehidupan sosial manusia. Masyarakat dunia mulai menaruh perhatian yang besar terhadap isu-isu seperti demokratisasi, Hak Asasi Manusia, kebebasan sipil, Good Governance, dan lain sebagainya. Tidak lagi suatu isu-isu domestik seperti ketimpangan, kemiskinan, buruknya kinerja pemerintah, dianggap hanya masalah satu Negara saja. Dengan semain terintegrasinya Negara-negara di dunia (terutama dalam bidang ekonomi), maka performa satu Negara akan sangat dipengaruhi dan pada gilirannya akan mempengaruhi Negara lain.

Seiring dengan perubahan tersebut, maka konsep kekuatan Negara juga mengalami perluasan makna. Jika sebelumnya definisi utamanya berkaitan dengan relasi eksternal (kemapuan untuk "mengontrol" pihak lain), maka dimensi lain dari konsep kekuatan lebih menekankan pada sisi internal. Yang dimaksud dengan sisi internal disini adalah keberadaan (existence) dari suatu Negara tersebut dan menurut Barry Buzan terbagi lagi menjadi tiga yakni : 1) the idea of the state, 2) the institutional expression of the state, dan 3) the physical base of the state (Buzan, 1983:36-65). Ketiga bagian tersebut merupakan unsur penting dari keberlangsungan (survival) dari suatu Negara. Perkembangan konsep ini didasari oleh fenomena runtuh atau pecahnya satu Negara yang disebabkan bukan karena agresi dari pihak luar, namun lebih kepada lunturnya kohesivitas internal. Oleh sebab itu, kekuatan Negara bisa dilihat dari seberapa mampu negara tersebut dalam menjaga ketiga unsur yang dikemukakan oleh Buzan sebelumnya.

Pergeseran definisi kekuatan ini juga didukung oleh data-data terkait perbandingan antara tren konflik antar Negara dan konflik domestik. Setidaknya ditemukan tren konflik antar Negara (interstate wars) yang menurun baik frekuensi maupun besarnya (Roser, 
2017; Szayna, Watts, Mahony, Frederick, \& Kavanagh, 2015). Di sisi lain, mobilisasi massa yang menuntut pemerintah serta melakukan protes atas kinerja pemerintah semakin meningkat (Youngs, 2017:2). Hal ini menunjukkan bahwa tantangan terbesar suatu Negara dalam menjamin keberlangsungan hidupnya (survival) tidak lagi datang dari lingkungan eksternal, namun cenderung muncul dari dalam negeri.

Tuntutan yang berasal dari masyarakat apabila tidak diakomodasi dengan baik maka akan menciptakan krisis legitimasi terhadap sistem dan pemerintahan itu sendiri, sehingga disini letak pentingnya untuk memastikan bahwa performa pemerintah/Negara dalam melayani serta memenuhi tuntutan masyarakatnya dapat terlaksana dengan baik. Salah satu isu penting yang selalu menjadi kebutuhan masyarakat dimanapun mereka berada adalah tentang kepastian hukum dan pemenuhan ketertiban (order), keadilan (justice) dan keamanan (security). Memang jika dilihat dari data yang tersedia, tren yang ada menunjukkan perbedaan tingkat kepercayaan masyarakat terhadap sistem serta lembaga peradilan di Negara masing-masing (Rochelle \& Loschky, 2014:1). Meski demikian khusus untuk Indonesia, kepercayaan masyarakat terhadap sistem dan lembaga peradilan Indonesia merupakan yang terendah diantara Negara-negara Asia Tenggara, selain itu pula performa lembaga peradilan Indonesia tercatat tidak terlalu bagus jika dibandingkan dengan sektor lainya (Indikator Politik Indonesia, 2016:11; Rochelle \& Loschky, 2014:1; World Justice Project, 2019a:3).

Kondisi di atas membuat lembaga peradilan Indonesia berada dalam posisi yang penting dalam kaitannya dengan kekuatan Negara. Mampu atau tidaknya Indonesia untuk mempertahankan eksistensinya sebagai suatu Negara salah satunya bergantung pada performa lembaga peradilan yang diharapkan mampu untuk memenuhi rasa keadilan yang dituntut oleh masyarakat. Oleh sebab itu tulisan ini akan mencoba untuk mendeskripsikan desain kelembagaan pada sistem peradilan Indonesia yang secara umum terdiri dari tiga lembaga: Mahkamah Konstitusi (MK), Mahkamah Agung (MA), dan Komisi Yudisial (KY). Setelah melalui transformasi besar pasca reformasi, desain kelembagaan sistem peradilan Indonesia merefleksikan model Institutional Pluralism. Model tersebut merupakan model alternatif dari desentralisasi administrasi yang ditawarkan oleh John Cohen dan Steven Peterson bagi Negara-negara berkembang. Secara singkat model itu merujuk pada "..multiple channels for service provision" atau pelayanan yang diberikan oleh lebih dari satu lembaga (saluran/channel) (Cohen \& Peterson, 1997:2-7, 1999:84). Kelebihan dari model tersebut adalah adanya aspek akuntabilitas yang mendasari Institutional Pluralism. Dengan demikian suatu lembaga tidak dimungkinkan untuk memonopoli penyediaan layanan serta akan dilengkapi dengan lembaga lain yang tugasnya melakukan checks and balance terhadap lembaga tersebut.

Hal ini yang agaknya terjadi pada sistem dan lembaga peradilan Indonesia pasca reformasi, dimana semangat pembentukan Mahkamah Konstitusi dan Komisi Yudisial diantaranya adalah melakukan check and balance terhadap Mahkamah Agung yang sebelumnya memonopoli sistem peradilan. Meski demikian, dari sekian banyak kelebihan yang ditawarkan oleh model Institutional Pluralism, dalam prakteknya, tumpang tindih serta konflik antar lembaga bisa saja terjadi dan justru lebih menghambat pencapaian tujuan dalam melayani masyarakat sehingga memunculkan pertanyaan "apakah Institutional Pluralism sebagai desain sistem dan lembaga peradilan Indonesia bisa berimplikasi positif terhadap kekuatan Negara?"

Untuk itu, artikel ini mencoba untuk menjawab pertanyaan tersebut dengan menggunakan pendekatan yang dikembangkan dalam studi Administrasi Negara dan Hubungan Internasional karena terdapat keterkaitan yang erat dalam topik yang diangkat. 
Kekuatan negara merupakan salah satu kajian utama dalam studi Hubungan Internasional, dan dalam perkembangannya, kekuatan negara tidak hanya dipandang dari sisi militer namun juga internal setting dari suatu negara. Pada bagian internal setting inilah kajian Administrasi Negara masuk untuk melengkapi kepingan penjelasan yang dibutuhkan.

Artikel ini akan mendeskripsikan beberapa hal yang terkait dengan topik pembahasan yang dimulai dengan pembedahan terhadap konsep Institutional Pluralism, konsep kekuatan negara, serta pembahasan singkat terkait dengan Mahkamah Agung, Mahkamah Konstitusi dan Komisi Yudisial. Secara teoritis, artikel ini diharapkan bisa memberikan kontribusi sebagai salah satu referensi tentang keterkaitan antara internal setting dengan kekuatan negara yang dibedah dengan pendekatan lintas disiplin yakni Administrasi Negara dan Hubungan Internasional. Artikel ini akan mencoba untuk memberikan sedikit pandangan dari perspektif globalisasi terkait dengan fungsi dan wewenang MK, MA, dan KY sebagai institusi yang bertugas untuk menyediakan rasa keadilan dalam proses bernegara di tengah arus globalisasi yang bagi sebagian penstudi merupakan suatu keniscayaan yang tidak dapat dielakkan (Hammarlund, 2005:27; Ohmae,

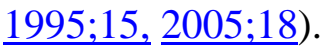

\section{B. METODE PENELITIAN}

Penelitian ini merupakan penelitian kualitatif deskriptif yang menggambarkan kaitan antara desain ketatanegaraan terutama pada sistem dan lembaga peradilan Indonesia dengan model Institutional Pluralism-nya dan kekuatan negara yang dilihat dari kemampuannya untuk menajaga kohesivitas internal. Penelitian kualitatif sendiri adalah penelitian yang bermaksud untuk menafsirkan suatu fenomena sosial secara holistik dengan menggunakan narasi (Moleong, 2013;35). Pengambilan data diperoleh melalui studi kepustakaan terkait dengan konsep-konsep utama yang menjadi topik pembahasan melalui dokumen-dokumen dan literatur yang memuat informasi yang dibutuhkan dalam penelitian. Terkait dengan teknik analisis data akan digunakan teknik statistik deskriptif yang bertujuan untuk memvisualisasikan data-data pendukung yang memperkuat argumen utama.

\section{KERANGKA KONSEP}

\section{Institutional Pluralism}

Model Institutional Pluralism secara singkat merujuk pada penyediaan layanan publik (service provision) yang dilakukan oleh beberapa stakeholders. Model ini dikembangkan oleh John Cohen dan Steven Peterson pada akhir tahun 1990-an dalam tulisan mereka yang berjudul "Administrative Decentralization: A New Framework for Improved Governance, Accountability, and Performance" serta "Administrative Decentralization: Strategies for Developing Countries" (Cohen \& Peterson, 1997:2, 1999:1). Tujuan utama dua ilmuwan tersebut adalah untuk menyediakan kerangka strategi bagi pengambil kebijakan serta lembaga-lembaga donor di banyak Negara berkembang dalam mengatasi permasalahan dan tantangan seputar pemerintahan seperti memperkuat tata pemerintahan, meningkatkan transparansi dan akuntabilitas serta penyediaan dan pendistribusian barang dan layanan publik yang lebih efektif dan efisien. Selain itu model yang mereka kembangkan juga dimaksudkan untuk mendobrak "monopoli" yang dilakukan oleh institusi sentral serta menawarkan jalan alternatif bagi penyediaan barang dan layanan publik. 
Menurut Cohen dan Peterson jika dilihat dari perspektif peran terdapat tiga desain strategi administratif. Peran yang dimaksud disini utamanya adalah peran institusi dalam menyediakan barang dan layanan. Selanjutnya klasifikasi tersebut ditentukan oleh bagaimana peran-peran itu dikonsentrasikan yakni, 1) Institutional Monopoly; 2) Distributed Institutional Monopoly, 3) Institutional Pluralism (Cohen \& Peterson, 1997:27, 1999:84; Geisler \& De Sousa, 2001:3). Desain pertama, Institututional Monopoly merujuk pada suatu sentralisasi peran hanya pada suatu organisasi atau institusi saja. Karakteristik desain ini adalah kadar hirarki yang tegas (top-down) yang dikomandoi oleh satu pusat. Kelemahan model ini menurut Cohen dan Peterson adalah ketidakmampuannya untuk merespon transformasi di lingkungan serta menghadapi tantangan yang terus bergerak dinamis. Selanjutnya adalah Distributed Institutional Monopoly atau desentralisasi administratif kepada institusi pemerintah pada tingkat lokal/daerah atau sektor swasta maupun organisasi lain melalui dekonsentrasi, devolusi dan/atau delegasi. Meski peran-peran tersebut didistribusikan namun control utama tetap berada pada institusi pusat. Dengan kata lain monopoli dari institusi pusat tidak terganggu, hanya saja beberapa peran yang sebelumnya ia jalankan ada beberapa yang ditransfer ke insitusi tingkat daerah. Desain terakhir adalah Insitutional Pluralism dimana peran penyediaan barang dan layanan publik dilakukan oleh berbagai institusi baik dari pihak pemerintah maupun swasta. Di sini monopoli dari satu lembaga tidak diberikan celah, dan Negara berperan sebagai "broker" atau "wasit" yang bertugas memastikan terselenggaranya kegiatan pemenuhan barang dan layanan publik dengan semestinya.

Lebih lanjut, Cohen dan Peterson berargumen bahwa dalam kerangka strategi yang mereka formulasikan tersebut terdapat satu komponen yang disebut principles of design. Untuk itu desain yang mereka rujuk bagi Negara-negara berkembang adalah desain Institutional Pluralism. Menurut mereka, rendahnya kualitas barang dan layanan publik yang diberikan oleh pemerintah di Negara-negara berkembang sangat dipengaruhi oleh sifat monopolistik dari institusi penyedia layanan tersebut. Absennya "kompetitor" dalam penyediaan barang dan layanan publik membuat masyarakat bergantung pada produk lembaga tersebut bagaimanapun kualitasnya. Pada gilirannya kondisi ini tidak memberikan stimulan bagi lembaga tersebut untuk memperbaiki diri. Institutional Pluralism bertujuan untuk meruntuhkan monopoli tersebut dan memunculkan "kompetitor" sekaligus "pemonitor" sebagai unsur checks and balances sehingga berpangkal pada meningkatnya akuntabilitas. Cohen dan Peterseon menunjukkan bahwa penerapan desain Institutional Pluralism yang sukses bisa dilihat pada contoh kasus 100 Cities Programme di Meksiko (Geisler \& De Sousa, 2001:120).

Jika pada konsep awal, Institutional Pluralism dikembangkan pada dimensi administratif khususnya desentralisasi administratif antara pusat dan daerah, maka Geisler dan De Sousa menerapkannya pada dimensi politik dengan menggunakan studi kasus desentralisasi politik di Bolivia. Berfokus pada era presiden Gonzalo Sanchez de Lozada yang melakukan reformasi politik besar-besaran untuk mendistribusikan kekuatan politik pada etnis-etnis mayoritas di Bolivia. Reformasi tersebut berbuah pada dibentuknya lembaga-lembaga perwakilan baru di samping parlemen seperti Organizaciones Territoriales de Base dan Comite de Vigilancia. Pada gilirannya lembaga-lembaga tersebut saling mengisi dan "berkompetisi" untuk melakukan perannya sebagai lembaga perwakilan masyarakat yang menentukan jalannya pemerintahan (Geisler \& De Sousa, 2001:122). 


\section{Konsep Kekuasan Negara}

Kekuatan negara seringkali identik dengan kekuatan militer dalam arti kuantitas dan kualitas persenjataan maupun personil yang dimiliki oleh suatu negara tersebut. Selain itu, kekuatan negara juga kerap disamakan dengan kapasitas ekonomi, sumberdaya alam, maupun luas teritorial yang ia kuasai. Meski demikian untuk memahami kekuatan negara dalam kerangka akademis, setidaknya dalam studi Hubungan Internasional dikenal nama Barry Buzan sebagai seorang akademisi yang banyak melahirkan tulisan-tulisan yang membahas mengenai tema keamanan serta kekuatan negara. Menurut Buzan, kekuatan negara bisa dilihat dari kadar eksistensinya, dan eksistensi suatu negara terdiri dari 3 unsur yang saling mendukung, yakni: 1) the idea of the state, 2) the institutional expression of the state, dan 3) the physical base of the state (Buzan, 1983:36-65). Suatu negara baru bisa dikatakan negara apabila ia memenuhi ketiga unsur diatas.

Buzan berpendapat bahwa kekuatan suatu negara bisa dilihat dari derajat ketiga unsur tersebut. Apabila ketiga unsur tersebut terpenuhi secara merata, maka kuatlah negara tersebut, dan apabila ketiga unsur tersebut tidak terpenuhi secara maksimal serta tidak merata, maka lemahlah ia. Kekuatan negara sendiri bisa diartikan sebagaimana yang disebutkan oleh Dauvergne yakni "the willingness and ability of a state to maintain social control, ensure societal compliance with official laws, act decisively, make effective policies, preserve stability and cohesion, encourage societal participation in state institutions, provide basic services, manage and control the national economy, and retain legitimacy" (Dauvergne, 1998:125). Oleh sebab itu absenya "the willingness" dan ability untuk melakukan hal-hal di atas merupakan ciri-ciri dari negara lemah.

Selain itu terdapat pula hubungan yang erat antara konsep kekuatan versi Buzan ini dengan konsep lain yang tidak kalah penting dalam ilmu Politik yakni konsep kedaulatan (sovereignty) dan Legitimasi. Kedaulatan merupakan konsep yang sarat akan perdebatan dan terus mengalami perkembangan dalam ilmu politik. Namun secara umum kedaulatan merujuk pada suatu supremasi tertinggi yang bisa digunakan untuk menjelaskan posisinya pada suatu institusi (biasanya negara) dan pengimplementasiannya dalam masyarakat. Maka dari itu konsepsi kedaulatan bisa berbeda jika konteks penyematannya berbeda. Jika merujuk pada kedaulatan negara (national sovereignty) definisinya menjadi "supreme public power, which has the right and, in theory, the capacity to impose its authority in the last instance" (kekuasaan publik tertinggi yang memiliki hak dan dalam teorinya memiliki kapasitas untuk memaksakan otoritasnya jika diperlukan) (De Benoist, 1999:99).

Sedangkan jika dialamatkan pada rakyat (individu) maka definisinya menjadi "..holder of legitimate power, who is recognized to have authority" (..pemegang kekuasaan sah yang mana dianggap sebagai pemilik kewenangan) (De Benoist, 1999:99). Sedangkan legitimasi merujuk pada keabsahan sesuatu. Dalam kaitannya dengan institusi Negara maka suatu institusi negara dianggap memiliki legitimasi apabila rakyat menyetujui bahwa kewenangnnya adalah sah (Gilley, 2006:499). Dengan demikian konsep kedaulatan dan legitimasi sangat erat hubungannya dalam kehidupan politik. Kedaulatan dan legitimasi merupakan penopang utama dari dua unsur pertama dari konsep kekuatan Buzan.

\section{Institusi Penyedia Keadilan: MA, MK, dan KY Mahkamah Agung}

Kewenangan Mahkamah Agung diatur dalam Pasal 24A UUD 1945 yang meliputi kewenangan untuk mengadili kasus hukum pada tingkat kasasi, menguji peraturan perundang-undangan di bawah undang-undang, dan kewenangan lain yang diberikan oleh 
undang-undang. Sebagai institusi yudikatif, Mahkamah Agung memiliki beberapa fungsi: 1) Fungsi Peradilan; 2) Fungsi Pengawasan; 3) Fungsi Pengaturan; 4) Fungsi Pemberi Nasehat; dan 5) Fungsi Administratif.

Selain itu dalam Undang-Undang Nomor 3 Tahun 2009, dijelaskan kembali secara lebih lengkap bahwa tugas dan wewenang MA adalah: 1) Mengadili pada tingkat kasasi terhadap putusan yang diberikan pada tingkat terakhir oleh pengadilan di semua lingkungan peradilan yang berada di bawah MA; 2) Menguji peraturan perundangundangan di bawah undang-undang; 3) Pernyataan tidak berlakunya peraturan perundangundangan sebagai hasil pengujian dimaksud dapat diambil baik dalam pemeriksaan tingkat kasasi maupun berdasarkan permohonan langsung terhadap MA; dan 4) MA melakukan pengawasan tertinggi atas perbuatan pengadilan dalam lingkungan peradilan yang berada di bawahnya berdasarkan ketentuan undang-undang.

\section{Mahkamah Konstitusi}

Mahkamah Konstitusi Republik Indonesia merupakan lembaga negara yang terbilang baru dalam sistem ketatanegaraan Indonesia dimana lembaga ini merupakan hasil dari perubahan Undang-Undang Dasar Negara Republik Indonesia Tahun 1945. Sebagai organ negara yang terkait erat dengan konstitusi, lembaga ini didesain untuk menjadi pengawal dan sekaligus penafsir terhadap Undang-Undang Dasar melalui putusan-putusan yang dikeluarkannya. Dalam Menjalankan tugas konstitusionalnya, Mahkamah Konstitusi berupaya mewujudkan visi kelembagaannya yaitu: "Tegaknya konstitusi dalam rangka mewujudkan cinta negara hukum dan demokrasi demi kehidupan kebangsaan dan kenegaraan yang bermartabat". Visi tersebut menjadi pedoman bagi Mahkamah Konstitusi dalam menjalankan kekuasaan kehakiman yang diembannya secara merdeka dan bertanggungjawab sesuai dengan amanat Undang-Undang Dasar Negara Republik Indonesia Tahun 1945. Sebagai organ konstitusi, lembaga ini didesain untuk menjadi pengawal dan sekaligus penafsir terhadap Undang-Undang Dasar melalui putusanputusannya. Dalam Menjalankan tugas konstitusionalnya, Mahkamah Konstitusi berupaya mewujudkan visi kelembagaannya yaitu: "Tegaknya konstitusi dalam rangka mewujudkan cinta negara hukum dan demokrasi demi kehidupan kebangsaan dan kenegaraan yang bermartabat". Visi tersebut menjadi pedoman bagi Mahkamah Konstitusi dalam menjalankan kekuasaan kehakiman yang diembannya secara merdeka dan bertanggungjawab sesuai dengan amanat Undang-Undang Dasar Negara Republik Indonesia Tahun 1945 (“Sejarah Pembentukan Mahkamah Konstitusi," n.d.).

Sebagaimana termuat dalam Pasal 24C UUD 1945, MK memiliki empat kewenangan dan satu kewajiban yakni: 1) Mengadili pada tingkat pertama dan terakhir yang putusannya bersifat final untuk menguji undang-undang terhadap Undang-Undang Dasar; 2) Memutus sengketa kewenangan lembaga Negara yang kewenangannya diberikan pada Undang-Undang Dasar; 3) Memutus pembubaran partai politik; dan 4) Memutus perselisihan tentang hasil pemilihan umum.

Sedangkan kewajiban MK adalah memeriksa, mengadili, dan memutus pendapat dari DPR apabila DPR menyatakan bahwa Presiden dan/atau Wakil Presiden telah melakukan pelanggaran hukum yang bisa berupa pengkhianatan terhadap Negara, terlibat korupsi, penyuapan, tindak pidana berat atau perbuatan tercela, serta memutus pendapat yang menyatakan bahwa Presiden dan/atau Wakil Presiden tidak lagi memenuhi syarat untuk tetap menjabat sebagai Presiden dan/atau Wakil Presiden. Kewenangan itu hanya akan dapat terlaksana apabila putusan itu (impeachment) didukung oleh sekurang- 
kurangnya dua per tiga dari jumlah anggota DPR yang hadir dalam sidang paripurna yang dihadiri oleh sekurang-kurangnya dua per tiga dari jumlah anggota DPR.

\section{Komisi Yudisial}

Komisi Yudisial merupakan institusi yang sedikit berbeda dari rumpun lembaga yudikatif di Indonesia karena institusi ini tidak memiliki kekuasaan kehakiman dalam pengertian menegakkan hukum dan keadilan serta memutus perkara, meskipun dalam Undang-Undang Dasar 1945 memuat pembahasan mengenai Komisi Yudisial dalam Bab IX tentang Kekuasaan Kehakiman. Dalam Pasal 24B ayat (1) Undang-Undang Dasar 1945 disebutkan bahwa "Komisi Yudisial bersifat mandiri yang berwenang mengusulkan pengangkatan hakim agung dan mempunyai wewenang lain dalam rangka menjaga dan menegakkan kehormatan, keluhuran martabat, serta perilaku hakim".

Selain itu kewenangan KY juga diatur melalui Udang-Undang No. 22 Tahun 2004 sebagaimana diubah melalui Undang-Undang 18 Tahun 2011 yang menyatakan bahwa: 1) KY memiliki kewenangan untuk mengusulkan pengangkatan hakim agung dan hakim ad hoc di Mahkamah Agung kepada DPR untuk mendapatkan persetujuan DPR; 2) Menegakkan kehormatan dan keluhuran martabat serta menjaga perilaku hakim; 3) Menetapkan Kode Etik dan/atau Pedoman Perilaku Hakim (KEPPH) bersama-sama dengan Mahkamah Agung; dan 4) Menjaga dan menegakkan pelaksaaan Kode Etik dan/atau Pedoman Perilaku Hakim (KEPPH).

Berkaitan dengan kewenangannya untuk menjaga dan menegakkan kehormatan, keluhuran martabat serta perilaku hakim, KY memiliki tugas untuk: 1) Melakukan pemantauan dan pengawasan perilaku hakim; 2) Menerima laporan dari masyarakat berkaitan dengan pelanggaran Kode Etik dan/atau Pedoman Perilaku Hakim; 3) Melakukan verifikasi, klarifikasi, dan investigasi terhadap laporan dugaan pelanggaran Kode Etik dan/atau Pedoman Perilaku Hakim secara tertutup; 4) Memutuskan benar tidaknya laporan dugaan pelanggaran Kode Etik dan/atau Pedoman Perilaku Hakim; dan 5) Mengambil langkah hukum dan/atau langkah lain terhadap orang perseorangan, kelompok orang, atau badan hukum yang merendahkan kehormatan dan keluhuran martabat hakim.

\section{HASIL DAN PEMBAHASAN}

\section{Negara dan Jaminan Keadilan}

Keadilan (justice) merupakan salah satu atau mungkin bagi beberapa orang merupakan alasan utama mengapa manusia memerlukan negara. Mengapa demikian? karena pada dasarnya keadilan merupakan prasyarat bagi hampir semua tujuan-tujuan lain dibentuknya negara seperti kesejahteraan dan kebebasan, meskipun terdapat pandangan yang berbeda terutama dari pemikir tradisi liberal yang tidak ingin membatasi pemenuhan kebutuhan manusia akan keadilan itu semata-mata hanya pada negara. Keadilan menciptakan rasa aman (security) yang kemudian menjadi landasan bagi setiap aktivitas manusia dalam memaksimalkan potensi dirinya, seperti mengenyam pendidikan setinggitingginya, menyejahterakan keluarga melalui aktivitas perekonomian, mengorganisir komunitas, sampai pada hal-hal seperti rekreasi, dan penyaluran bakat-bakat pada masingmasing individu.

Rasa aman (security) yang bersumber dari keadilan itu kemudian erat hubungannya dengan keteraturan (order), bahkan kajian mengenai order and justice merupakan kajian inti ilmu politik yang sudah berlangsung selama ratusan tahun. Kondisi dimana tidak terdapat keteraturan dalam suatu komunitas (chaos) merupakan situasi ketika manusia bisa 
memangsa manusia lainnya (homo homini lupus) sehingga dalam perkembangannya para pemikir ilmu politik, beserta turunannya seperti ilmu administrasi negara dan hubungan internasional berusaha dengan sangat keras untuk mempelajari konsep-konsep mengenai order, justice dan security dan berupaya untuk menemukan cara agar ketiganya bisa diciptakan dan ditegakkan dalam kehidupan manusia.

Agaknya tidak berlebihan apabila kita mengatakan bahwa studi administrasi negara berputar pada permasalahan order. Fokus-fokus terhadap efektifitas, efisiensi, kinerja organisasi dan lain sebagainya menemukan landasan yang sama, yakni untuk mencipatakan semacam keteraturan dalam suatu organisasi demi pencapaian tujuannya. Pada gilirannya, keteraturan tersebut akan menciptakan rasa keadilan serta memberikan jaminan keamanan baik bagi organisasi maupun anggota organisasi terutama bila kita berbicara tentang organisasi publik.

Tradisi realis sangat mempercayai institusi modern bernama Nation-State atau negara seperti yang kita kenal saat ini sedangkan liberalis tidak ingin membatasi pemenuhan order and justice hanya pada institusi negara, bahkan order and justice bagi mereka bisa dipenuhi oleh intitusi Suprastate. Diskusi mengenai isu itu juga semakin dinamis dengan munculnya paradigma atau perspektif baru yang muncul seiring dengan berkembangnya ilmu yang membahas mengenai hubungan antar negara ini. Pandanganpandangan alternatif seperti Konstruktivisme, Post-Modernisme, Feminisme, Teori Kritis untuk menyebut sebagian turut mewarnai diskusi dengan asumsi-asumsi dasar yang sangat berbeda dengan asumsi tradisi besar sebelumnya. Hasilnya adalah diskusi mengenai order, justice, and security yang sangat dinamis serta membuka wawasan bagi siapapun yang memiliki minat dalam kajian ini.

Seperti yang telah disinggung sebelumnya, bahwa sedemikian pentingnya order, justice dan security ini maka muncul pemikiran bahwa hanya suatu entitas politik yang kuat, membawahi semua anggota komunitas yang bisa menegakkan atau lebih tepatnya memaksakan order tercipta dalam kehidupan masyarakat. Entitas ini kemudian yang akan bertanggung jawab untuk menyediakan rasa aman dan rasa keadilan bagi seluruh anggotanya. Itulah entitas politik modern yang dinamakan negara. Pemikiran ini sangat dipengaruhi oleh tradisi realis khususnya pemikiran Thomas Hobbes dalam bukunya Leviathan yang inti pendapatnya adalah bagaimana sifat dasar manusia dan lingkungannya itulah yang cenderung menciptakan chaos (Donnelly, 2005:30; Elman, 2007:11). Dari sini timbul pemikiran bahwa untuk "menjinakkan" chaos itu maka diperlukan negara yang memiliki wewenang (authority) terhadap seluruh penduduknya dan dengan wewenang itu negara menciptakan order, justice dan security. Meski demikian pada prakteknya dengan wewenang yang sangat kuat, negara justru tampil sebagai penindas masyarakatnya dan kenyataan ini membuat banyak ilmuan politik kemudian memikirkan ulang perihal negara dan wewenangnya.

Pada perjalanannya kajian mengenai negara dalam ilmu politik semakin berkembang hingga pada kajian mengenai struktur negara atau yang kita kenal sekarang ini dengan Ilmu Tata Negara. Salah satu konsep yang paling terkenal adalah mengenai pembagian kekuasaan Negara menjadi tiga cabang yakni cabang Eksekutif, Legislatif, dan Yudikatif atau yang dikenal dengan Trias Politica. Konsep yang dikembangkan oleh Montesquieu ini menariknya justru dipengaruhi oleh pemikir Liberalis yakni John Locke yang kemudian dengan teori kontrak sosialnya mendirikan basis bagi perkembangan konsep demokrasi. Hadir sebagai lawan pemikiran bagi tradisi Realis, postulat utama dari konsep tersebut adalah kekuasaan yang terpusat pada satu orang atau entitas tertentu cenderung disalahgunakan sehingga perlu untuk dibagi menjadi tiga cabang dan masing- 
masing cabang itu berfungsi sebagai penyeimbang kekuasaan bagi yang lainnya. Kekuasaan untuk menjalankan pemerintahan dipegang oleh eksekutif, kekuasaan untuk membuat undang-undang serta sebagai lembaga perwakilan dipegang oleh legislatif, dan yang terakhir kekuasaan dalam bidang peradilan dipegang oleh yudikatif.

Seiring dengan diadopsinya sistem demokrasi secara luas oleh negara-negara di dunia termasuk di Indonesia, maka hal yang sama berlaku pula untuk Indonesia dimana Presiden beserta jajarannya memegang kekuasaan eksekutif, Majelis Permusyawarahan Rakyat (MPR), Dewan Perwakilan Rakyat (DPR) dan Dewan Perwakilan Daerah (DPD) memegang kekuasaan legislatif dan kekuasaan yudikatif diberikan kepada Mahkamah Konstitusi (MK), Mahkamah Agung (MA) dan Komisi Yudisial (KY).

\section{Tantangan Globalisasi Bagi Sistem Peradilan}

Meskipun demikian, pada hakikatnya semua perkembangan teori maupun konsep dalam Ilmu Politik dan Ilmu Tata Negara yang dibahas sebelumnya tidak terlepas dari usaha manusia untuk memahami kehidupan sosial serta menciptakan order, justice dan security pada masyarakat menurut tradisi pemikirannya masing-masing. Upaya mulia dari para pemikir bidang ilmu tersebut mendapatkan tantangan besar di era globalisasi seperti saat ini. Globalisasi sendiri secara sederhana dimaknai sebagai compression of the world yang diakibatkan oleh meningkatnya saling ketergantungan (interdependence) global (Robertson, 1992:30). Globalisasi merupakan salah satu kajian inti dari Ilmu Hubungan Internasional yang kemudian memuat banyak sekali persinggungan dengan aspek, konsep dan teori yang dikembangkan pada Ilmu Politik dan Ilmu Administrasi.

Salah satu isu global yang menjadi perhatian dunia internasional adalah demokratisasi. Penyebaran demokrasi telah menjadi agenda internasional dengan dilatarbelakangi gagasan tentang kedamaian dan keadilan yang turut menyertai konsep tersebut. Bahkan demokrasi telah menjadi semacam norma internasional yang tidak hanya berfungsi sebagai panduan namun juga sebagai pintu masuk dalam pergaulan internasional. Kepercayaan yang tinggi terhadap keberhasilan demokrasi tidak datang begitu saja, namun didukung oleh data-data yang menunjukkan adanya korelasi yang kuat antara demokrasi Hak Asasi Manusia, dan tingkat kesejahteraan dari suatu Negara. Berdasarkan perbandingan GDP, ditemukan bahwa Negara yang menganut sistem demokrasi jauh lebih makmur dibandingkan dengan Negara yang non demokrasi kecuali Negara non demokrasi yang berperan sebagai eksportir minyak seperti Qatar. Selain itu di Negara-negara demokrasi, Hak Asasi Manusia dan kualitas pendidikan juga lebih baik dibandingkan dengan Negara non demokrasi (Roser, 2016:1).

Serangkaian keberhasilan itu membuat penyebaran demokrasi menjadi agenda global dan penetrasi dari promotor demokrasi ini begitu kuat sehingga seringkali Negara yang mencoba untuk menolak demokrasi biasanya akan berhadapan dengan rakyatnya yang menginginkan demokrasi. Promotor demokrasi tidak hanya datang dari Negaranegara besar saja namun juga berasal dari organisasi internasional non pemerintah maupun individu yang didukung oleh sumberdaya yang besar seperti CIVICTUS, Carter Center, maupun individual semacam George Soros yang turut aktif mempromosikan demokrasi ke seluruh dunia (Payne, 2017:45).

Tercatat pasca Perang Dunia II jumlah Negara demokrasi mengalami peningkatan meski perlahan. Baru ketika Perang Dingin berakhir dan Uni Soviet dinyatakan bubar, jumlah demokrasi meningkat dengan signifikan. Sampai pada tahun 2016, dari 167 negara yang memiliki penduduk diatas 500.000 jiwa, terdapat 97 negara demokrasi atau 58\% 
dibandingkan dengan Negara otokrasi yang berjumlah 21 (13\%) dan 49 (26\%) negara yang memiliki karakteristik keduanya (Desilver, 2017:2; Roser, 2016:1).

Tabel 1.

\begin{tabular}{cr}
\multicolumn{2}{c}{ Jumlah Peningkatan Demokrasi Di Dunia } \\
\hline Tahun & Jumlah Demokrasi \\
\hline 1945 & 17 \\
1955 & 25 \\
1967 & 33 \\
1975 & 34 \\
1986 & 42 \\
1995 & 73 \\
2005 & 85 \\
2010 & 87 \\
2016 & 97
\end{tabular}

Sumber: diolah dari Desilver, 2017:2; dan Roser, 2016:1.

Demokrasi membawa perubahan besar yakni terjadinya penguatan civil society terhadap kekuasaan Negara. Dengan kebebasan yang dijamin dalam demokrasi, maka masyarakat tidak lagi hanya menjadi objek dari kekuasaan namun juga sebagai subjek yang turut berpartisipasi dalam menentukan arah pembangunan. Penyelewengan atas kekuasaaan Negara serta tidak terpenuhinya hak-hak warga negara bisa dikontrol serta dituntut oleh warga negara dalam iklim demokrasi. Sehingga tidak mengherankan apabila demonstrasi dan protes marak terjadi ketika kinerja Negara tidak sebaik yang diharapkan. Hal ini bisa dilihat dari tren peningkatan jumlah protes dan demonstrasi pada tingkat global yang utamanya menuntut transparansi, pemberantasan korupsi, penghentian penyelewengan kekuasaan Negara serta isu lain yang terkait (Youngs, 2017:3).

Yang menarik adalah berkat globalisasi demokratisasi juga menembus dindingdinding penghalang yang dibangun oleh Negara otoriter dan menghasilkan tuntutan dari tingkat akar rumput untuk mengganti sitem Negara. Kegagalan suatu Negara dalam merespon serta mengakomodasi tuntutan tersebut bisa berujung pada konflik yang berkepanjangan yang menghambat perekonomian dan kestabilan regional seperti yang terjadi pada Negara-negara di Timur Tengah dan Afrika Utara atau yang lebih dikenal dengan fenomena Arab Spring.

Salah satu tuntutan penting lainnya terkait dengan topik sentral dalam tulisan ini yakni keadilan. Menurut laporan yang dikeluarkan oleh World Justice Project, terdapat sekitar 5.1 miliar penduduk dunia yang belum mendapatkan keadilan secara penuh. Angka ini terbagi lagi dalam beberapa kategori yakni; 1.5 miliar orang yang tidak mampu mendapatkan keadilan dalam urusan sipil, administratif dan kriminal. Orang-orang ini hidup di Negara yang memiliki institusi peradilan yang berfungsi namun tetap mendapatkan hambatan dalam memperoleh hak-hak keadilannya. Yang kedua adalah 4.5 miliar orang yang tidak memiliki akses hukum. Mereka adalah orang-orang yang tidak memiliki dokumen pendukung yang disyaratkan dalam sistem peradilan seperti kartu identitas, surat kepemilikan tanah atau properti, surat kontrak kerja dan lain sebagainya. Dengan demikian mereka tidak mampu untuk melindungi aset yang mereka miliki serta tidak mampu mengakses layanan yang disediakan oleh Negara. Terakhir adalah 253 orang yang hidup dalam kondisi ketidakadilan yang parah. Mereka adalah orang-orang yang tidak memiliki Negara, termasuk dalam sistem perbudakan modern atau mereka yang 
hidup di Negara konflik yang rentan terhadap ketidakadilan (World Justice Project, 2019b:4).

Fenomena di atas bisa memberi gambaran bahwa kondisi sistem peradilan di seluruh dunia sedang mengalami masalah yang serius dimana banyak orang tidak mendapatkan rasa keadilan yang mereka harapkan. Dengan diadopsinya sistem demokrasi secara luas, maka tuntutan akan pemenuhan rasa keadilan tersebut tentu saja menjadi salah satu tuntutan yang harus direspon dan diakomodasi oleh setiap pemerintahan di dunia, termasuk Indonesia. Tidak lagi bisa pemerintah bertindak otoriter dengan membungkam tuntutan tersebut serta menutup saluran-saluran terhadap hak-hak masyarakat. Situasi ini merupakan tantangan tersendiri bagi keberlangsungan suatu negara karena apabila Negara lalai dalam mengatasi tuntutan global ini, maka potensi kekacauan yang dapat mendestabilitaskan Negara akan sangat besar dan pada gilirannya akan menggerus kekuatan Negara.

\section{Transformasi Sistem dan Institusi Peradilan Indonesia}

Bersamaan dengan diadopsinya model pemerintahan Barat, maka arus liberalisasi dalam pemerintahan semakin meluas dengan diadopsinya pula skema-skema desentralisasi dan demokratisasi sistem pemerintahan. Tentu saja hal ini selaras dengan prinsip good governance yang menekankan pada aspek akuntabilitas, transparansi, keterbukaan dan supremasi hukum (Fernanda, 2006:5).

Dalam konteks Indonesia, transformasi ini telah berlangsung sejak berakhirnya Orde Baru. Arus perubahan menyentuh sektor-sektor yang sebelumnya dimonopoli oleh negara seperti ekonomi dan politik. Perubahan itu juga menyasar desain ketatanegaraan Indonesia yang mencerminkan keinginan untuk meletakkan nilai-nilai demokrasi dalam sistem ketatanegaraan tidak terkecuali sitem peradilan Indonesia.

Semangat reformasi yang menjadi narasi besar bagi setiap aktivis yang merasa rezim otoritarian Orde Baru sudah selayaknya dirubah dengan rezim pemerintahan yang lebih demokratis, menghargai HAM dan mencerminkan kedaulatan rakyat melalui intitusi/lembaga pelaksana kekuasaan negara pasca Soeharto. Tuntutan reformasi tersebut melahirkan perubahan-perubahan (amandemen) Undang-Undang Dasar 1945 yang sudah terjadi sebanyak empat kali yakni amandemen pertama pada 19 Oktober 1999, kedua pada Agustus 2000, ketiga pada November 2000, dan keempat pada Agustus 2002. Setelah melalui empat amandemen susunan lembaga negara adalah: Majelis Permusyawarahan Rakyat (MPR); Dewan Perwakilan Rakyat (DPR); Dewan Perwakilan Daerah (DPD); Presiden/Wakil Presiden (Lembaga Kepresidenan); Mahkamah Agung (MA); Mahkamah Konstitusi (KY); Komisi Yudisial (KY); dan Badan Pemeriksa Keuangan (BPK).

Empat amandemen konstitusi Indonesia sangat berpengaruh terhadap lanskap institusi Negara Indonesia yang kemudian melahirkan MK dan KY yang sebelum amandemen ketiga belum dibentuk. Selain itu amandemen konstitusi juga menyatakan secara tegas dalam Pasal 1 ayat (3) bahwa "negara Indonesia adalah negara hukum". Salah satu prinsip utama dalam Negara yang berlandaskan hukum adalah adanya jaminan penyelenggaraan kekuasaan kehakiman yang merdeka dan bebas dari pengaruh kekuasaan lainnya. Untuk itu dalam Pasal 24 ayat (1) UUD Negara Republik Indonesia Tahun 1945 disebutkan bahwa "Kekuasaan kehakiman merupakan kekuasaan yang merdeka untuk menyelenggarakan peradilan guna menegakkan hukum dan keadilan”. Sebelum reformasi kewenangan Mahkamah Agung (MA) sangatlah besar dalam wilayah yudikatif mulai dari memutuskan sengketa pemilihan umum sampai pada minimnya pengawasan dari institusi luar. Wewenang tersebut kemudian dipecah dan disebar kepada MK dan KY seperti saat 
ini kewenangan untuk memutuskan sengketa pemilu bukan lagi wewenang MA namun MK, dan KY sebagai institusi external yang mengawasi MA. Prinsip checks and balance pada ketatanegaraan Indonesia kemudian sangat terasa pada keempat amandemen konstitusi

Jika dicermati lebih dalam, ternyata hubungan kelembagaan dalam sistem peradilan Indonesia masih menyimpan berbagai permasalahan. Berdasarkan penjelasan singkat di atas dapat dipahami bahwa kewenangan yudikatif sebenarnya dipegang oleh MK dan MA sedangkan KY hanya berfungsi sebagai pengawas terutama bagi MA, namun KY tidak memiliki wewenang untuk mengawasi MK. Bagi sebagian orang hal ini sangat disayangkan, karena MK sebagai institusi penerjemah konstitusi serta memiliki kekuasaan untuk memakzulkan eksekutif ternyata tidak memiliki lembaga lain sebagai pengawas dalam mekanisme checks and balance sebagaimana MA di awasi oleh KY. MK lebih memilih untuk membentuk sendiri lembaga pengawas yang sudah barang tentu rawan terhadap konflik kepentingan. Satu-satunya lembaga eksternal yang berwenang untuk mengawasi MK adalah Badan Pemeriksa Keuangan (BPK) itupun hanya pada bidang audit keuangan (Komisi Yudisial Republik Indonesia, 2014:xi).

Selain itu yang seringkali berujung pada hubungan konfliktual adalah MA dan KY. Secara filosofis, KY dibentuk sebagai institusi pengawas eksternal MA, dan diberikan kewenangan untuk memberikan rekomendasi pemberhentian hakim MA serta pengusulan nama hakim agung. Meski demikian, banyak kalangan yang menagnggap bahwa kewenangan KY sangat terbatas sehingga tidak mampu melakukan fungsi pengawasan yang penuh. Hal ini dibuktikan dengan banyaknya rekomendasi dari KY yang tidak digubris oleh MA (Nathaniel, 2018:3). Di lain pihak, terdapat pula tudingan yang mengatakan bahwa komisioner KY banyak yang berlaku tidak adil terhadap hakim MA dengan melaporkan peristiwa yang tidak sesuai fakta sehingga mencederai martabat hakim. KY dinilai melakukan hal itu demi popularitas di mata publik (Ali, 2009:4; Diah Kusumawati, 2016:3; Supriyadi, 2015:2).

Tabel 2.

Rekomendasi KY yang ditolak dan diabaikan MA

Tahun Rekomendasi KY yang ditolak dan diabaikan MA

2009-2010 KY mengajukan rekomendasi kepada MA untuk menjatuhkan hukuman disiplin kepada 91 hakim. Namun MA tidak menindaklanjuti semua rekomendasi

2011 MA menolak rekomendasi KY yang meminta agar majelis hakim kasus Antasari Azhar dilarang menangani perkara selama 6 bulan

2013 MA menolak rekomendasi KY untuk menjatuhkan sanksi berat terhadap Daming Sanusi

2015 MA menolak rekomendasi KY terkait dugaan pelanggaran kode etik hakim Sarpin Rizaldy

2017 Dari 33 rekomendasi hukuman pelanggaran kode etik oleh KY, 18 diantaranya belum dilaksanakan oleh MA

2018 MA mengabaikan banyak rekomendasi sanksi 58 hakim oleh KY.

Sumber : Nathaniel, 2018:3.

Berdasarkan deskripsi di atas, agaknya bisa dikatakan bahwa Institutional Pluralism dalam sistem peradilan Indonesia masih belum terimplementasi dengan penuh. Ada beberapa indikator yang bisa digunakan. Pertama adalah tentang hubungan yang tidak berimbang antar lembaga, terutama dari sisi KY yang tidak diberikan kewenangan yang besar dalam hal pengawasan terhadap MA. Selain itu tidak ada aturan yang mengatur 
tentang sanksi bagi MA yang seringkali mengabaikan rekomendasi KY. Kedua, hampir tidak ada hubungan yang signifikan antara KY dan MK. Ketiga, beberapa tudingan menyebutkan bahwa KY hanya mencari popularitas dalam memberikan rekomendasi terhadap hakim MA, sehingga perlu dipertanyakan siapa yang kemudian berhak untuk mengawasi KY?

Sejatinya Institutional Pluralism yang dikembangkan oleh Cohen dan Peterson bertujuan untuk menyuntikkan elemen pengawasan dan kompetisi dalam suatu sistem agar tercipta lingkungan yang akuntabel. Geisler dan De Sousa lantas menerapkan prinsip Institutional Pluralism dan mengaplikasikannya pada dimensi politik di Bolivia yang menghasilkan berbagai institusi perwakilan yang saling melengkapi. Dalam kasus yang diangkat oleh Cohen \& Peterson serta Geisler \& De Sousa memang didapatkan fakta tentang keberhasilan atau setidaknya harapan yang menjanjikan terkait dengan penerapan Institutional Pluralism. Meski demikian, perlu diingat bahwa tidak semua kasus penerapan Institutional Pluralism berhasil. Terdapat banyak literatur yang menunjukkan gagalnya model tersebut untuk diimplementasikan di berbagai sektor seperti kesehatan, pendidikan, dan perumahan (Deeds \& Pattillo, 2015:1; Phiri \& Guven-Uslu, 2018:150; Sanyal \& Mukhija, 2001:2054; Subedi \& Subedi, 2004:64). Mungkin hubungan kelembagaan dalam sistem peradilan Indonesia bisa menjadi contoh kasus tambahan gagalnya Institutional Pluralism, meskipun kita juga bisa mengatakan bahwa kegagalan itu adalah hasil dari belum sempurnanya pengadopsian model itu dalam sistem peradilan Indonesia. Apapun itu hubungan kelembagaan yang tidak harmonis dan konfliktual dalam sistem peradilan Indonesia berpengaru terhadap persepsi masyarakat tentang kapabilitas Negara dalam menyediakan rasa keadilan bagi mereka.

\section{Kondisi Sistem Peradilan Indonesia dan Kekuatan Negara}

Sebagaimana telah dijelaskan pada bagian sebelumnya, kekuatan Negara dalam tulisan ini lebih condong pada pendapat yang menekankan pada kekuatan yang terejawantahkan ke dalam (internal setting). Kekuatan itu kemudian berhubungan erat dengan kedaulatan dan legitimasi rakyat terhadap Negara beserta lembaganya. Dalam hal ini mereka merefleksikan dua unsur kekuatan Negara menurut Buzan yakni the idea of the state dan the institutional expression of the state.

Kedaulatan rakyat dipertaruhkan dalam desain institusi yang tepat. Kedaulatan rakyat merupakan konsep yang dikembangkan untuk melawan ketidakadilan Negara yang menyalahgunakan wewenangnya alih-alih sebagai entitas yang menyediakan order, justice and security bagi masyarakat. Berangkat dari tradisi pemikiran di era Pencerahan Eropa, kedaulatan rakyat sangat menitikberatkan pada hak-hak individu dalam menentukan arah kehidupannya termasuk dalam urusan politik dimana hal ini dikaitkan dengan keterlibatan rakyat dalam pengambilan keputusan politik yang akan mengikat masyarakat secara luas. Demokrasi menawarkan pola relasi politik representatif yang dituangkan dalam intitusiinstitusinya. Dengan demikian kedaulatan rakyat dianggap terwakili oleh institusi politik demokratis termasuk disini institusi penyedia keadilan seperti MA, MK dan KY pada contoh Indonesia. Hal ini juga menyangkut tentang kewenangan (authority) institusi dan kedaulatannya (sovereignity) sebagai suatu institusi yang memiliki basis legitimasi yang berakar dari konsesus rakyat dalam kehidupan demokrasi.

Hal inilah yang berkaitan erat dengan tema tulisan ini. Pertanyaan krusial adalah "apakah institusi-institusi Negara penyedia keadilan masih memiliki legitimasi di mata rakyat"?. Pertanyaan ini penting karena akan berimplikasi pada kekuatan Negara sebagai variabel yang ingin dijelaskan dalam tulisan ini. 
Pembahasan akan bergeser dari desain ketatanegaraan macam apa yang paling bisa menjamin terciptanya order, justice and security menjadi kepada siapa/instutusi mana masyarakat bisa mengharapkan order, justice and security dikarenakan rendahnya kepercayaan masyarakat terhadap institusi Negara. Model Institutional Pluralism yang menajanjikan akuntabilitas ternyata tidak sepenuhnya dijalankan dalam sistem peradilan Indonesia sebagaimana pada penjelasan pada bagian sebelumnya.

Konsekuensinya adalah pandangan apatis yang menyatakan bahwa siapapun presiden, menteri, anggota legislatif, pejabat yudikatif, keadaan akan tetap seperti ini. Tentu saja pandangan yang sangat determinis ini berpotensi menyimpan kekuatan revolusi ketika masyarakat sudah kehilangan rasa percaya pada institusi Negara. Tren ketidakpercayaan publik terhadap kinerja lembaga peradilam Indonesia menunjukkan kenaikan dari tahun ke tahun.

Tabel 3.

Tingkat Ketidakpuasan Masyarakat Terhadap Penegakan Hukum

\begin{tabular}{lr}
\hline Bulan/Tahun & Ketidakpuasan Terhadap Penegakan Hukum \\
\hline Januari 2010 & $37 \%$ \\
Oktober 2010 & $41,2 \%$ \\
September 2011 & $50,3 \%$ \\
Oktober 2012 & $50,3 \%$ \\
April 2013 & $56 \%$ \\
\hline
\end{tabular}

Sumber: Badan Pembinaan Hukum Nasional Kementerian Hukum dan Hak Asasi Manusia, 2015:1-2

Selain itu, kasus-kasus korupsi yang menjerat pimpinan institusi penyedia keadilan seperti kasus-kasus suap hakim dan penangkapan Ketua Mahkamah Konstitusi semakin memperburuk kondisi kepercayaan masyarakat terhadap lembaga peradilan ini. Survey yang dilakukan oleh Indikator Politik Indonesia pada 18-29 Januari 2016 memberikan data bahwa institusi peradilan menduduki posisi 3 terbawah sebagai institusi yang tidak bisa dipercaya setelah DPR dan Parpol (Indikator Politik Indonesia, 2016:11).

Tabel 4.

Tingkat Kepercayaan Masyarakat Terhadap Lembaga Negara

\begin{tabular}{lr}
\hline Institusi & Tingkat Kepercayaan Publik \\
\hline KPK & $79.6 \%$ \\
Kepresidenan & $79.2 \%$ \\
Kepolisian & $68.9 \%$ \\
Pengadilan & $57.9 \%$ \\
DPR & $48.5 \%$ \\
Partai Politik & $39.2 \%$ \\
\hline
\end{tabular}

Sumber: Indikator Politik Indonesia, 2016:11

Hal ini sebenarnya sangat berkaitan dengan kekuatan Negara bahkan apabila dibiarkan, Negara Indonesia bisa saja terhapus dalam peta dunia dan terpecah belah sebagaimana Yugoslavia terpecah-pecah menjadi puluhan Negara. Tentu saja hal tersebut harus dihindari karena ongkos sosialnya sangat besar. Kekuatan Negara tidak serta merta hanya berkaitan dengan aspek militer saja, namun lebih kompleks dari itu. Kekuatan Negara merupakan interaksi antara aspek ide (ideas) dan material. Barry Buzan mengemukakan pendapatnya terkait dengan hal ini. Disebutkannya bahwa untuk 
mengatakan bahwa Negara itu kuat atau lemah perlu dilihat tiga aspek yang saling berkaitan yakni the idea of the state, the institution of the state, dan the physical base of the state (Buzan, 1983:36-65). Pertama ide tentang Negara memuat konsensus masyarakat Negara tersebut perihal Negara yang mereka tempati, intinya keberadaan Negara tersebut terletak pada ide yang dipercaya oleh masyarakat. Hal ini bisa kita kaitkan dengan konsep Imagine Community yang dikembangkan oleh Benedict Anderson ketika mendeskripsikan Indonesia bahwa keberadaan Indonesia, sangat berkaitan dengan ide tentang Indonesia itu sendiri yang dipercaya oleh penduduknya. Selanjutnya institusi Negara, yang merupakan mesin penggerak jalannya pemerintahan, dan yang terakhir adalah aspek fisik dari Negara seperti wilayah.

Kekuatan Negara secara komprehensif ditentukan oleh interaksi ketiga komponen kekuatan tersebut, bukan hanya pada satu aspek saja. Mungkin saja saat ini, nampaknya hampir ketiga komponen tersebut digrogoti baik dari lingkup domestik maupun penetrasi eksternal. Contoh konkrit misalnya bagaimana putusan MK terkait dengan gugatan masyarakat yang berpendapat bahwa Undang-Undang Nomor 7 Tahun 2004 Tentang Pengelolaan Sumber Daya Air, kemudian Undang-Undang Nomor 22 Tahun 2001 Tentang Minyak Bumi dan Gas Alam, dan Undang-Undang Nomor 20 Tahun 2002 Tentang Ketenagalistrikan.

Para Pemohon berpendapat bahwa ketiga UU tersebut bertentangan dengan semangat yang terkandung dalam Pasal 33 UUD 1945 yang menyatakan bahwa : a) Cabang-cabang produksi yang penting bagi Negara dan yang menguasai hajat hidup orang banyak, dan b) Bumi dan air dan kekayaan alam yang terkandung di dalamnya yang harus dipergunakan untuk sebesar-besarnya kemakmuran rakyat (Kuntana, Junaenah, \& Ahmad Taufik, 2010:111). Namun dalam putusannya MK memilih untuk memutuskan bahwa UU No. 7/2004 tidak bertentangan dengan konstitusi, mengabulkan sebagian gugatan pemohon dalam UU No. 22/2001 dan mengabulkan gugatan pemohon pada UU No. 20/2002.

Putusan MK tersebut memang menimbulkan banyak diskusi di kalangan masyarakat, dan akan sangat memakan waktu apabila disinggung dalam tulisan ini. Poin yang ingin dibahas adalah bahwa dengan wewenang MK sebagai penafsir konstitusi tunggal dan terakhir, hal yang ditakutkan adalah bagaimana apabila tafsir MK bertentangan dengan kehendak masyarakat banyak? Dan terlebih secara sosial terasa sangat "salah"?. Misalnya pandangan bahwa Indonesia merupakan Negara yang sangat kaya dengan sumber daya alam namun pada kenyataannya SDA tersebut dikuasai asing (MNCs) karena tafsir "dikuasai" dalam Pasal 33 konstitusi bisa diartikan hanya sebagai pengelola?. Tentu saja MK memiliki personalia yang berkompeten untuk membahas hal ini meski demikian potensi human error tetap terbuka lebar. Permasalahannya kemudian apabila error itu merupakan hal yang disengaja (corrupt). Situasi akan sangat beresiko mengingat apapun putusan MK, hal itu bersifat tetap, mengikat dan akhir. Konsekuensinya dari kekhawatiran tersebut adalah anggapan bahwa perlunya mekanisme checks and balance untuk mengimbangi dan mengontrol perilaku MK. Seperti yang telah dijelaskan sebelumnya, tulisan ini berargumen bahwa dari sisi Ketatanegaraan, maka hal ini bisa diatasi mungkin dengan memperbesar peran dan wewenang KY sebagai lembaga penjaga etik peradilan. Namun bukan itu intinya. Sebenarnya pembahasan akan bisa dilanjutkan kepada: "jika demikian, siapa yang mengontrol KY?", kemudian "siapa yang akan mengontrol institusi yang mengontrol KY" dan seterusnya sampai pada tingkatan asumsi atau biasa dalam pengalaman spiritual manusia disebut dengan tahapan leap of faith. Kita percaya saja pada satu entitas/institusi/orang tanpa mempertanyakan lebih lanjut. 
Mungkin pembaca akan melihat hal ini sebagai kekonyolan, tapi menurut penulis hal ini ada dan sangat terasa, paling tidak secara subjektif. Dalam situasi ini maka aksioma kepercayaan itu akan sangat ditentukan oleh citra dan persepsi masyarakat sebagai basis legitimasi/kebasahan institusi negara. Jika satu institusi dianggap bersih terlepas dari benar atau tidaknya maka semakin legitimate lah institusi tersebut, dan sebaliknya. Apakah tidak ada sistem objektif dalam mengukur kinerja institusi itu? Tentu saja ada namun biasanya hal itu merupakan laporan/temuan resmi yang dikeluarkan oleh lembaga yang ditugaskan untuk mengawasi, namun seperti yang telah disebutkan sebelumnya, hal itu tidak sesederhana seperti yang terlihat. Kita dipaksa untuk kemudian bersandar pada argument atomis yang begitu klise namun sangat benar bahwa semua terpulang kepada manusianya.

\section{E. PENUTUP}

Institutional Pluralism sebagai model desain kelembagaan sistem peradilan Indonesia yang diharapkan mampu untuk menciptakan akuntabilitas di dunia peradilan Indonesia ternyata jauh dari harapan. Alih-alih menyediakan suatu sistem yang memperkuat akuntabilitas serta legitimasi lembaga, justru yang terjadi adalah konflik antar lembaga peradilan Indonesia terutama antara MA dan KY yang banyak menyita perhatian. Desain ini ternayata tidak berdaya dalam menurunkan ketidakpercayaan masyarakat terhadap lembaga peradilan Indonesia yang dibuktikan dengan menurunnya ketidakpercayaan publik terhadap kinerja lembaga peradilan dari tahun ke tahun. Selain karena adopsi Institutional Pluralism yang tidak sempurna, hal ini juga diperparah oleh penyelewengan kekuasaan dari pimpinan lembaga peradilan tersebut. Dalam kontek kekuatan Negara yang dibahas dalam tulisan ini, maka internal setting dari suatu Negara sangat berperan dalam menjaga keberlangsungan Negara tersebut. Negara yang kuat adalah Negara yang berhasil mempertahankan tiga unsur kekuatan Negara yakni 1) the idea of the state, 2) the institutional expression of the state, dan 3) the physical base of the state. Dua unsur pertama dari kekuatan Negara tersbut sangat erat kaitannya dengan legitimasi yang dihasilkan dari akuntabilitas lembaga Negara. Dengan gagalnya lembaga peradilan Indonesia dalam meningkatkan citra mereka di mata publik, maka bisa dikatakan bahwa legitimasi lembaga peradilan Indonesia juga turut menurun. Dalam era globalisasi dimana tuntutan publik terhadap penegakan hukum sangat besar, maka hal ini mencerminkan ketidakberhasilan Negara dalam merespon tuntutan tersebut. Apabila hal ini terus dibiarkan, maka hilangnya legitimasi lembaga peradilan akan berkontribusi terhadap menurunnya kekuatan Negara dalam menjaga the idea of the state dan the institutional expression of the state.

\section{DAFTAR PUSTAKA}

Ali. (2009). Menakar Hubungan MA-KY Pasca Revisi UU MA. Retrieved from https://www.hukumonline.com/berita/baca/hol20927/menakar-hubungan-maky-pascarevisi-uu-ma

Badan Pembinaan Hukum Nasional Kementerian Hukum dan Hak Asasi Manusia. (2015). Laporan Akhir Tim Penelitian Hukum Tentang Peran Penegak Hukum Dalam Rangka Meningkatkan Kepercayaan Publik Kepada Lembaga Peradilan. Jakarta.

Buzan, B. (1983). People, States, and Fear: the National Problem in International Relations. International Journal, 40(4), 756-758. https://doi.org/10.2307/40202323

Cohen, J., \& Peterson, S. (1997). Administrative Decentralization: A New Framework for Improved Governance, Accountability, and Performance. Development Discussion $\begin{array}{llll}\text { Paper, } & 582, & 39 . & \text { Retrieved }\end{array}$ 
https://pdfs.semanticscholar.org/6668/8ea676a8cc2fd417f7c6dee17f81b592d510.pdf

Cohen, J., \& Peterson, S. (1999). Administrative Decentralization: Strategies for Developing Countries. West Hartford, CT.: Kumarian Press.

Dauvergne, P. (1998). Weak and strong states in the societies of the Asia Pacific. Pacific Economic Bulletin, 13(1), 124-131.

De Benoist, A. (1999). Sovereignty, survival and the Westphalian blind alley in International Relations. Review of International Studies, 25(2), 217-231. doi:10.1017/S026021059900217X

Deeds, V., \& Pattillo, M. (2015). Organizational "Failure" and Institutional Pluralism: A Case Study of an Urban School Closure. Urban Education, 50(4), 474-504. https://doi.org/10.1177/0042085913519337

Desilver, D. (2017). Despite Concerns About Global Democracy, Nearly Six-In-Ten Countries Are Now Democratic. Retrieved from Pew Research Center website: https://www.pewresearch.org/fact-tank/2017/12/06/despite-concerns-about-globaldemocracy-nearly-six-in-ten-countries-are-now-democratic/

Diah Kusumawati, U. (2016). Jokowi Soroti Hubungan MA dan KY yang Kurang Mesra. Retrieved from https://www.cnnindonesia.com/nasional/20160304212912-12115435/jokowi-soroti-hubungan-ma-dan-ky-yang-kurang-mesra

Donnelly. (2005). Realism. In S. Burchill, A. Linklater, R. Devetak, M. Paterson, C. ReusSmit, \& J. True (Eds.), Theories of Interrnational Relations (Third Edit, pp. 29-54). https://doi.org/10.1017/CBO9781107286207.002

Elman, C. (2007). Realism. In M. Griffiths (Ed.), International Relations Theory for the Twenty-First Century: An Introduction (pp. 11-20). https://doi.org/10.4324/9780203939031

Fernanda, D. (2006). Paradigma New Public Management (NPM) Sebagai Kerangka Reformasi Birokrasi Menuju Kepemerintahan yang Baik (Good Governance) di Indonesia. Jurnal Borneo Administrator, 2(3), 1-16.

Geisler, C., \& De Sousa, R. (2001). Insitutional pluralism in public administration and politics: Applications in Bolivia and beyond. Public Administration and Development, 21(2), 119-129. https://doi.org/10.1002/pad.154

Gilley, B. (2006). The meaning and measure of state legitimacy, results for 72 countries. European Journal of Political Research, 45(3), 499-525.

Hammarlund, P. A. (2005). Liberal Internationalism and the Decline of the State: The Thought of Richard Cobden, David Mitrany and Kenichi Ohmae. New York: Palgrave Macmillan.

Indikator Politik Indonesia. (2016). Revisi UU KPK dan Pertaruhan Modal Politik Jokowi, Temuan Survei Nasional: 18-29 Januari 2016. Retrieved from www.indokator.co.id

Komisi Yudisial Republik Indonesia. (2014). Studi Perbandingan Komisi Yudisial di Beberapa Negara (Cetakan Pe). Jakarta: Sekretariat Jenderal Komisi Yudisial Republik Indonesia.

Kuntana, M., Junaenah, I., \& Ahmad Taufik, G. (2010). Tafsir MK Atas Pasal 33 UUD 1945: Studi Atas Putusan MK Mengenai Judicial Review Terhadap UU No. 7/2004, UU No. 22/2001, dan UU No. 20/2002. Jurnal Konstitusi, 7(1), 111-180.

Moleong, L. J. (2013). Metodologi Penelitian Kualitatif. Bandung: PT. Remaja Rosdakarya.

Nathaniel, F. (2018). Cuma Bikin Ribut Tapi Tak Punya Kekuatan, Haruskah KY Dibubarkan? Retrieved from tirto.id website: https://tirto.id/cuma-bikin-ribut-tapitak-punya-kekuatan-haruskah-ky-dibubarkan-cZHb 
Ohmae, K. (1995). The End of the Nation State: The Rise of the Regional Economies. New York: The Free Press.

Ohmae, K. (2005). The Next Global Stage: Challenges and Opportunities in our Borderless world. In Challenges and Opportunities in Our Borderless World (Vol. 27). https://doi.org/10.1111/j.1744-6570.2007.00071_3.x

Payne, R. J. (2017). Global issues: politics, economics, and culture (Fifth Edit). New York: Pearson.

Phiri, J., \& Guven-Uslu, P. (2018). Institutional pluralism, two publics theory and performance reporting practices in Zambia's health sector. Journal of Accounting in Emerging Economies, 8(1), 141-162. https://doi.org/10.1108/JAEE-07-2017-0074

Robertson, R. (1992). Globalization: Social Theory and Global Culture. London: SAGE Publications.

Rochelle, S., \& Loschky, J. (2014). Confidence in Judicial Systems Varies Worldwide. Retrieved from Gallup website: https://news.gallup.com/poll/178757/confidencejudicial-systems-varies-worldwide.aspx

Roser, M. (2016). Democracy. Retrieved from Our World In Data website: https://ourworldindata.org/democracy\#number-of-democracies

Roser, M. (2017). The Share of Battle Deaths is Declining even Faster. Retrieved from https://ourworldindata.org/war-and-peace\#the-share-of-battle-deaths-is-decliningeven-faster

Sanyal, B., \& Mukhija, V. (2001). Institutional pluralism and housing delivery: A case of unforeseen conflicts in Mumbai, India. World Development, 29(12), 2043-2057. https://doi.org/10.1016/S0305-750X(01)00082-1

Sejarah Pembentukan Mahkamah Konstitusi. (n.d.). Retrieved from https://mkri.id/index.php?page=web.ProfilMK\&id=1\&menu=2

Subedi, J., \& Subedi, S. (2004). Institutional Pluralism: The Incomplete Differentiation of Health Care in Nepal. Central Issues in Anthropology, 10(1), 61-66. https://doi.org/10.1525/cia.1992.10.1.61

Supriyadi, E. (2015). DPD: Hubungan Lembaga Yudikatif Perlu Dievaluasi. Retrieved from https://www.republika.co.id/berita/dpd-ri/berita-dpd/15/08/20/ntdvt1254-dpdhubungan-lembaga-yudikatif-perlu-dievaluasi

Szayna, T. S., Watts, S., Mahony, A. O., Frederick, B., \& Kavanagh, J. (2015). What Are the Trends in Armed Conflicts, and What Do They Mean for U. S. Defense Policy? Retrieved from https://www.rand.org/content/dam/rand/pubs/research_reports/RR1900/RR1904/RAN D_RR1904.pdf

World Justice Project. (2019a). Indonesia. Retrieved from http://data.worldjusticeproject.org/\#/groups/IDN

World Justice Project. (2019b). Measuring the Justice Gap: A People-Centered Assesment of Unmet Justice Needs Around the World. Washington D.C.

Youngs, R. (2017). What Are the Meanings Behind the Worldwide Rise in Protest? Retrieved from opendemocracy website: https://carnegieeurope.eu/2017/10/02/whatare-meanings-behind-worldwide-rise-in-protest-pub-73276 
